\title{
Composition and Degradation of Jackrabbit and Cottontail Fecal Pellets, Texas High Plains
}

\section{JERRAN T. FLINDERS AND JOHN A. CRAWFORD}

Highlight: Fecal pellets were taken from black-tailed jackrabbits and desert cottontail rabbits for studies of rates of natural degradation. Microscopic analyses of fecal samples showed a significant difference in the proportion of grasses, forbs, and woody plants ingested by the two leporid species sampled. Jackrabbits had ingested greater proportions of grasses and woody plants while cottontails had ingested greater proportions of forb material. Degradation of fecal pellets was observed at regular intervals from 1972 to 1974 . Time required for complete disappearance of pellets was estimated at 4.4 years for jackrabbits and 9.5 years for cottontails. Relative humidity and precipitation were strongly correlated $(r=-0.98$ and -0.95 for jackrabbits and cottontails, respectively) with disappearance of pellets.

This study of black-tailed jackrabbits (Lepus californicus) and desert cottontail rabbits (Sylvilagus auduboni) was designed to consider the following: comparisons of the vegetational composition of dietary material; short-term degradation (including disappearance) of fecal pellets in typical habitat; and the relationship between fecal pellet degradation, pellet composition, and weather variables. Prediction equations were de-

\footnotetext{
Authors are associate professor and director, Wildlife and Range Resources Graduate Program, 407 WIDB, Brigham Young University, Provo, Utah 84602; and assistant professor, Department of Fisheries and Wildlite, Oregon State University, Corvallis, Oregon 97331 .

The authors thank Drs. B. J. Verts and M. Passmore of the Department of Fisheries and Wildlife at Oregon State University and D. N. Ueckert of the Department of Range Science, Texas A\&M University for their editorial help. Dr. C. R. Hatch, College of Forestry, Wildlife, and Range Science, University of Idaho, provided statistical counsel. Manuscript received April 9, 1976.
}

veloped for fecal pellet degradation over time and in relation to weather variables.

Counts of fecal pellets have been widely used as an indirect method of censusing several mammalian species. Most workers stressed the need to know defecation rate, time interval between counts, location and identification of all pellets in plots, and average weight of pellets produced and collected (Arnold and Reynolds 1943; Eberhardt and Van Etten 1956). Ferguson (1955) and Wallmo et al. (1962) investigated effects of weather and other factors on deterioration of fecal material and, thus, the pellet-group counts of deer.

Arnold and Reynolds (1943) suggested using fecal pellets for estimating jackrabbit population densities and amounts of forage removed by jackrabbits, but they did not consider effects of degradation of pellets over time. Kundaeli and Reynolds (1972) recognized this problem, for they made only relative population predictions from their annual counts of desert cottontail fecal pellets in New Mexico. Hansen (1972) used numbers of black-tailed jackrabbit pellets collected at 3-month intervals in northeastern Colorado to predict amounts of forage removed by these hares. Cochran and Stains (1961) quantified the deposition of fecal pellets by eastern cottontail rabbits ( $S$. floridanus) under penned conditions. Their studies showed degradation rates differed with type of habitat and diet; possible utilization of pellets by invertebrates was noted. Lord (1963) found that rain hastened the disappearance of eastern cottontail fecal pellets, but felt earthworms ingested many pellets. 


\section{Study Area and Methods}

This study was conducted on the Texas Tech University Experimental Farm at Lubbock, Tex. Buffalograss (Buchloe dactyloides), blue grama (Bouteloua gracilis), catclaw mimosa (Mimosa biuncifera), and honey mesquite (Prosopis glandulosa) were the dominant plants on the study area. Twelve black-tailed jackrabbits and 7 desert cottontails were collected in the evening hours of June 15-16, 1972. This time of day was selected for collection because these leporids produce and reingest soft fecal material, from the cecum, in the morning hours and have reverted to production of hard fecal pellets by evening (Hansen and Flinders 1969). Sex was noted, and age of the animals was determined by body weight and degree of closure of the epiphyseal line at the proximal end of the humerus. Digestive tracts were removed for processing. Fecal pellets were removed from the lower end of the colon of each animal. These fecal pellets were identical in compaction, size, and appearance to freshly voided feces found in the field. Five pellets from each leporid were used for dietary studies. These were dried in an oven at $70^{\circ} \mathrm{C}$ and then ground in a mill over a 1-mm screen. Two microscope slides were prepared from each fecal sample after the sample was washed over a $0.1-\mathrm{mm}$ screen. Ten microscope fields were examined, under $100 \times$ magnification, on each of the two slides of fecal material for each leporid. Stomach contents were processed and examined in a like manner (Flinders and Hansen 1972).

The histological characteristics of plant epidermal tissues were used as the basis for identification of plant fragments. A reference collection of plant tissues from all plant species found in the study area was prepared for histological comparisons with stomach and fecal material. Percent frequency, recorded for each plant species identified in stomach contents and fecal pellets, was converted to particle density per microscope field (Fracker and Brischle 1944). Relative particle density for each plant species was used as an estimate of percent relative dry weight of each food item (Sparks and Malechek 1968). Kulczynski's Index of Similarity (Oosting 1956) was used to compare diets from stomach and fecal samples of each species. Chi-square analyses were used to test for proportionate differences in dietary samples. Plant frequency in the habitat was estimated in mid-July 1972 from 140 randomly placed $30 \times 60-\mathrm{cm}$ quadrats.

Pellet degradation was studied within a $2 \times 2-\mathrm{m}$ rabbit-proof (but not rodent-proof) exclosure, which was constructed in a stand of vegetation dominated by buffalograss (Fig. 1). Eight plots, $15 \mathrm{~cm}$ in diameter, of fine wire mesh $10 \mathrm{~cm}$ in height, of which $5 \mathrm{~cm}$ was buried, were arranged in a randomized block pattern within the exclosure. Fecal pellets removed from the lower colons of the leporids and not used for dietary studies were air-dried for 72 hours. Twenty fecal pellets, proportionately representative of the age and sex ratios of the

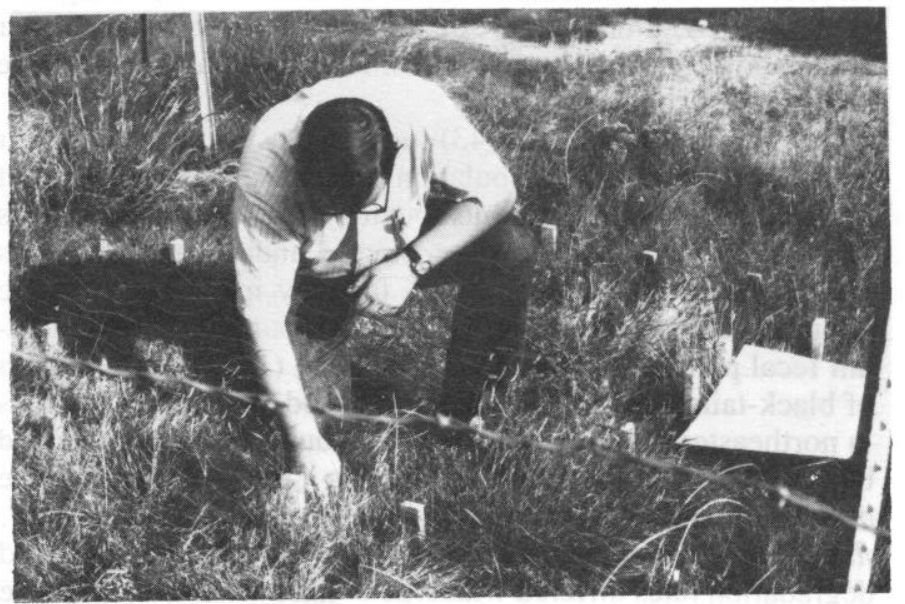

Fig. 1. Degradation rates of black-tailed jackrabbit and desert cottontail pellets were studied in a rabbit-proof exclosure. Four pellet groups, consisting of 20 pellets each, were used for each species; each pellet group was confined within a fine-mesh wire plot. animals collected, were placed in each of the 8 plots; jackrabbit pellets were placed in 4 of the randomly selected plots and cottontail pellets were placed on the other 4 . All naturally occurring leporid fecal pellets were removed from plots prior to the deposition of test samples. Fecal pellets were examined and counted weekly for the first 2 months, and then monthly for the remainder of the study period. Mean monthly precipitation, mean relative humidity, and mean air temperature were obtained from the U.S. Weather Bureau at the Lubbock airport (approximately $7 \mathrm{~km}$ from the study area).

Correlation analysis was used to determine the relationship between number of fecal pellets remaining and time elapsed. One-factor and multiple-factor regression analyses were used to determine the degree of association between number of pellets remaining in relation to the accumulated amount of average precipitation and accumulated average relative humidity (Kerlinger and Pedhazur 1973). Statistical tests were evaluated at the $5 \%$ level of significance. Percent relative humidity was transformed using

$$
\text { Angle }=\operatorname{arc} \sin \sqrt{\text { proportion }}
$$

as suggested by Woolf (1968) for data expressed as proportions or percents.

\section{Results and Discussion}

Eighteen plant species were identified in the samples from the stomachs and 16 plant species in the fecal samples of blacktailed jackrabbits. There was $86 \%$ similarity between the proportions of each plant species found in both stomach and fecal samples of these hares. Fifteen plant species were identified in the stomach and fecal samples of desert cottontail rabbits. We found $73 \%$ similarity between the proportions of each plant species in the stomach and fecal samples of these rabbits. Chisquare analyses showed no significant difference in the proportions of grasses, forbs, and woody plants within the stomach and fecal dietary samples for both black-tailed jackrabbits and desert cottontail rabbits. These comparisons indicate fecal material can be used to adequately represent the dietary composition of both leporids in our sample at this time of the year.

We found $65 \%$ similarity between the proportions of plant species in fecal pellets of black-tailed jackrabbits and desert cottontail rabbits. There was a significant difference in the proportions of grasses, forbs, and woody plants consumed by the two species of leporids. In desert cottontail feces, $47.2 \%$ of the dry weight was derived from forbs, while only $12.3 \%$ of the dry weight of jackrabbit feces was forb material. Thus, hares ingested greater proportions of grasses and woody plants than the rabbits. Sand dropseed (Sporobolus cryptandrus), summercypress (Kochia scoparia), and honey mesquite were the most important grass, forb, and woody plant, respectively, in the diets of both leporids; but dietary proportions were different (Table 1). Plants of importance in diets of both species were not those most available in the habitat according to our measurements of relative frequency.

Fecal pellets were placed in plots on July 1, 1972, and by July 9 there was an $11 \%$ decrease in the number of jackrabbit pellets and a $10 \%$ decrease in the number of cottontail pellets (Fig. 2). Fecal pellet degradation after the first 9 days was significantly different for the samples from the two leporid species. The linear correlation coefficient $(r)$ between number of fecal pellets remaining and time elapsed in months was +0.96 for jackrabbits. The regression coefficient $(b)$ associated with the linear model was -0.34 . Both values were significant. If this trend continued, it would take 4.4 years for complete degradation of the sample of jackrabbit pellets.

The same relationship was evaluated for cottontail fecal pellets, and the analysis yielded a correlation coefficient of 
Table 1. Relative percent frequency of plant species in the habitat and relative percent dry weight of plant species in fecal peliets of black-tailed jackrabbits and desert cottontail rabbits.

\begin{tabular}{|c|c|c|c|}
\hline Plant species & $\begin{array}{l}\text { ercent relative } \\
\text { frequency in } \\
\text { habitat }\end{array}$ & $\begin{array}{l}\text { Percent relative } \\
\text { dry weight in } \\
\text { jackrabbit feces }\end{array}$ & $\begin{array}{l}\text { Percent relative } \\
\text { dry weight in } \\
\text { cottontail feces }\end{array}$ \\
\hline \multicolumn{4}{|l|}{ Grasses and sedges } \\
\hline Aristida adscenscionis & - & 1.3 & 1.2 \\
\hline Aristida longiseta & 0.9 & - & - \\
\hline Bouteloua curtipendula & 0.9 & 1.3 & 3.1 \\
\hline Bouteloua gracilis & 20.7 & - & - \\
\hline Buchloe dactyloides & 12.2 & 1.3 & 0.6 \\
\hline Chloris verticellata & 0.9 & 0.6 & - \\
\hline Cyperus uniflorus & 0.9 & - & - \\
\hline Digitaria californica & 0.9 & 3.2 & - \\
\hline Eragrostis curtipedicellata & - & 2.6 & - \\
\hline Leptoloma cognatum & - & 1.3 & 1.2 \\
\hline Muhlenbergia arenicola & 0.9 & - & - \\
\hline Panicum obtusum & 6.0 & - & 2.4 \\
\hline Sitanion longifolium & 1.7 & 4.5 & 3.1 \\
\hline Sorghum halepense & - & 0.6 & - \\
\hline Sporobolus cryptandrus & 0.9 & 36.1 & 19.6 \\
\hline \multicolumn{4}{|l|}{ Forbs } \\
\hline Berlandiera lyrata & 1.7 & - & - \\
\hline Chamaesaracha sordida & 2.6 & - & - \\
\hline Euphorbia sp. & 7.8 & - & - \\
\hline Evolvulus nuttallianus & 0.9 & - & - \\
\hline Helianthus ciliaris & 0.9 & - & - \\
\hline Kochia scoparia & - & 8.4 & 25.8 \\
\hline Krameria lanceolata & 0.9 & - & 1.2 \\
\hline Machaeranthera tanacetifolia & 1.7 & - & - \\
\hline Mirabilis linearis & 1.7 & - & 1.2 \\
\hline Oxalis dillenii & 0.9 & - & - \\
\hline Physalis viscosa & 2.6 & - & - \\
\hline Ratibida columnaris & 3.4 & - & 0.6 \\
\hline Solanum elaeagnifolium & 2.6 & 1.3 & 16.0 \\
\hline Sphaeralcea coccinea & 3.4 & 2.6 & 2.4 \\
\hline Teucrium lacineatum & 3.4 & - & - \\
\hline Verbena sp. & 0.9 & - & - \\
\hline Zinnia gradiflora & 5.2 & - & - \\
\hline Unknown & 0.9 & - & - \\
\hline \multicolumn{4}{|l|}{ Woody plants } \\
\hline Mimosa biuncifera & 6.0 & - & - \\
\hline Opuntia polyacantha & - & 1.9 & 0.6 \\
\hline Prosopis glandulosa & 4.3 & 32.3 & 20.9 \\
\hline Yucca arkansana & - & 0.6 & - \\
\hline Xanthocephalum sarothrae & 2.6 & - & - \\
\hline
\end{tabular}

-0.98 . The regression coefficient associated with this linear model was -0.16 . These values were also significant. If we again assume a constant rate (with reference to the $b$ value) of disappearance, it would take 9.5 years for complete degradation of the sample of desert cottontail fecal pellets. Actual decomposition rates of all fecal pellets in the study plots after 2 years may not be linear or may not follow the linear model established during the reported nearly 2 years of study.

We can only speculate as to the cause for the significant difference in rate of fecal pellets. As noted, there were significant differences in the vegetative composition of the fecal pellets from the two leporid species. The smaller fecal pellets of cottontails may have penetrated deeper into the buffalograss turf and thus gained added protection from weather and other degenerative factors. Laboratory treatment and limited sample size must also be taken into account.

In considering those factors related to degradation of leporid fecal pellets, we found mean, relative humidity was slightly more effective than mean monthly precipitation in predicting degradation. For black-tailed jackrabbits, the correlation coefficient for the relationship between the number of fecal pellets remaining and accumulated mean monthly relative humidity

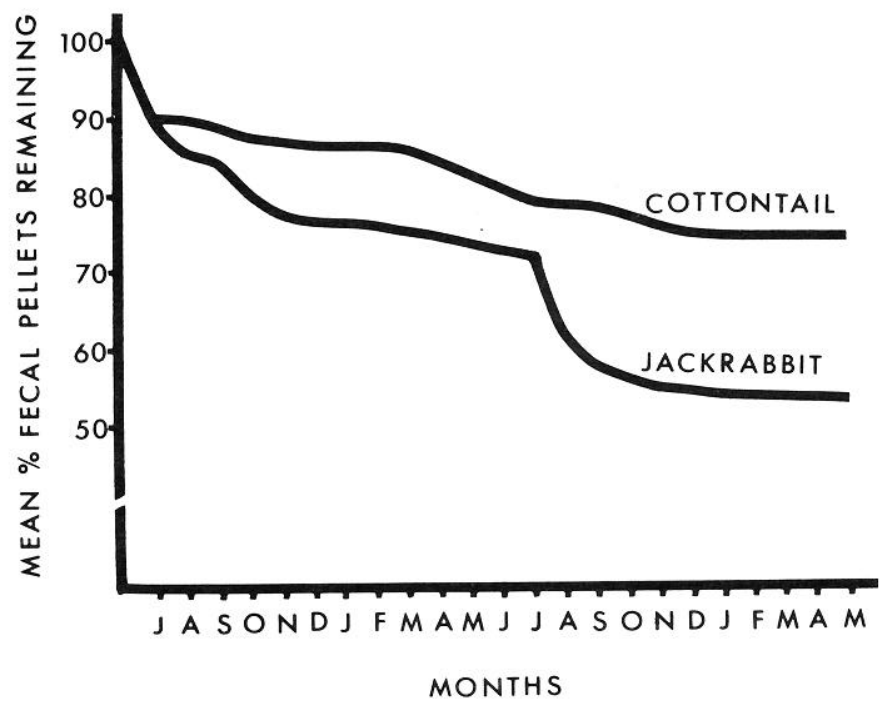

Fig. 2. Mean percent of fecal pellets remaining in exclosures for black-tailed jackrabbits and desert cottontails each month, July 1, 1972-May 1, 1974.

was $-0.96 ; r$ for the relationship between the number of fecal pellets remaining and accumulated mean monthly precipitation was -0.94 . Degradation of black-tailed jackrabbit fecal pellets may be predicted using

$$
\hat{\mathrm{Y}}=19.01-0.70 \chi_{\mathrm{i}}
$$

where $\hat{Y}$ refers to number of pellets remaining and $\chi_{i}$ refers to accumulated mean monthly relative humidity, and

$$
\hat{\mathrm{Y}}=19.98-0.27 \chi_{\mathrm{i}}
$$

where $\hat{Y}$ refers to number of pellets remaining and $\chi_{i}$ refers to accumulated mean monthly precipitation.

The correlation coefficient for the relationship between the number of desert cottontail fecal pellets remaining and accumulated mean monthly relative humidity was -0.98 . The correlation coefficient for this relationship using accumulated mean monthly precipitation was -0.95 . The number of desert cottontail fecal pellets remaining may be predicted using

$$
\hat{\mathrm{Y}}=18.36-0.33 \chi_{\mathrm{i}} \text {, }
$$

where $\hat{Y}$ refers to number of pellets remaining and $\chi_{i}$ refers to accumulated mean monthly relative humidity, and

$$
\hat{\mathrm{Y}}=19.23-0.12 \chi_{\mathrm{i}}
$$

where $\hat{Y}$ refers to number of pellets remaining and $\chi_{i}$ refers to accumulated mean monthly precipitation. Relative humidity

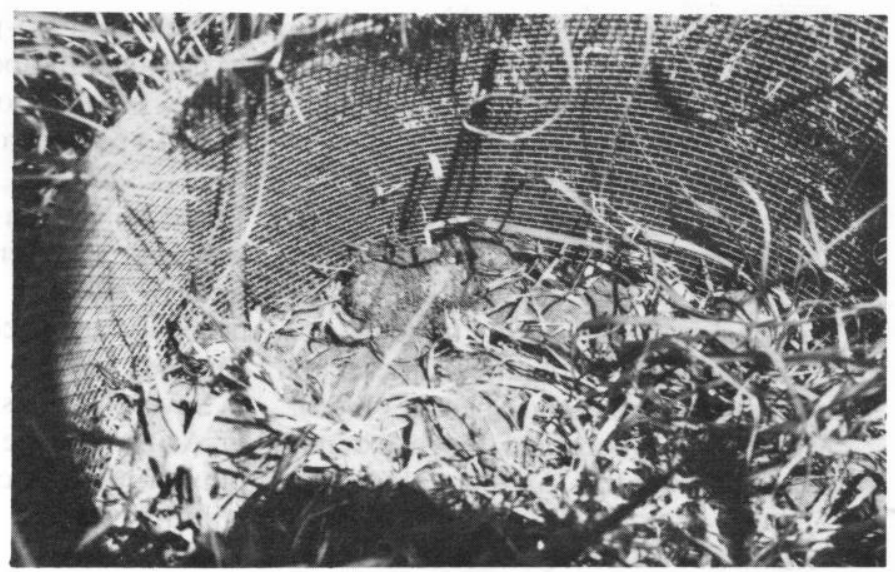

Fig. 3. Termite activity, influenced by weather, was an important factor in pellet degradation. Termite casts are shown in the center of the picture. 
and precipitation were correlated so highly $(r=0.96)$ that their use together in a multiple regression to predict disappearance of fecal pellets did not significantly add to the coefficient of multiple correlation.

The greatest amount of degradation of pellets occurred during summer and fall (Fig. 2). We noted that subterranean termites (Gnathitermes spp.) were responsible for $39 \%$ of the degradation during that time (Fig. 3). Haverty et al. (1974) demonstrated that termite activity was highly dependent on temperature and precipitation. Thus, while termites were responsible for much of the pellet degradation, the ultimate causative factors were weather components.

\section{Literature Cited}

Arnold, J. F., and H. G. Reynolds. 1943. Droppings of Arizona and antelope jack rabbits and the "pellet census." J. Wildl. Manage. 7:322-327.

Cochran, G. A., and H. J. Stains. 1961. Deposition and decomposition of fecal pellets by cottontails. J. Wildl. Manage. 25:432-435.

Eberhardt, L., and R. C. Van Etten. 1956. Evaluation of the pellet-group count as a deer census method. J. Wildl. Manage. 20:70-74.

Ferguson, R. B. 1955. The weathering and persistency of pellet groups as it affects the pellet group count method of censusing mule deer. Utah Acad. Sci. Proc. 32:59-64.
Flinders, J. T., and R. M. Hansen. 1972. Diets and habitats of jackrabbits in northeastern Colorado. Range Sci. Dep. Sci. Ser., Colorado State Univ. 12:1-29.

Fracker, S. B., and J. A. Brischle. 1944. Measuring the local distribution of Ribes. Ecology 25:283-303.

Hansen, R. M. 1972. Estimation of herbage intake from jackrabbit feces. J. Range Manage. 25:468-471.

Hansen, R. M., and J. T. Flinders. 1969. Food habits of North American hares. Range Sci. Dep. Sci. Ser., Colorado State Univ. 1:1-18.

Haverty, M. I., J. P. LaFage, and W. L. Nutting. 1974. Seasonal activity and environmental control of foraging of the subterranean termite, Heterotermes aureus (Snyder), in a desert grassland. Life Sci. 15:1091-1101.

Kerlinger, F. N., and E. J. Pedhazur. 1973. Multiple regression in behavioral research. Holt, Rinehart and Winston, Inc., New York. 534 p.

Kundaeli, J. H., and H. G. Reynolds. 1972. Desert cottontail use of natural and modified pinyon-juniper woodland. J. Range Manage. 25:116-118.

Lord, R. D., Jr. 1963. The cottontail rabbit in Illinois. Illinois Dep. Conserv. Tech. Bull. No. 3. 94 p.

Oosting, H. J. 1956. The study of plant communities. W. H. Freeman and Co., San Francisco. $440 \mathrm{p}$

Sparks, D. R., and J. C. Malechek. 1968. Estimating percentage dry weight in diets using a microscopic technique. J. Range Manage. 21:264-265.

Wallmo, O. C., A. W. Jackson, T. L. Hailey, and R. L. Carlisle. 1962. Influence of rain on the count of deer pellet groups. J. Wildlife Manage. 26:50-55

Woolf, C. M. 1968. Principles of biometry. D. Van Nostrand Co., Inc., Princeton, New Jersey. 359 p. 